Review

\title{
Research and development of a sub-critical methanol alcoholysis process for producing biodiesel using waste oils and fats
}

\author{
DU Zexue*, TANG Zhong, WANG Haijing, ZENG Jianli, CHEN Yanfeng, MIN Enze \\ Research Institute of Petroleum Processing, SINOPEC, Beijing 100083, China
}

\section{A R T I C L E I N F O}

\section{Article history:}

Received 30 August 2012

Accepted 8 November 2012

Published 20 January 2013

\section{Keywords:}

Biodiesel

Waste oils and fats

Methanol

Sub-critical methanol alcoholysis

Transesterification

Esterification

\begin{abstract}
A B S T R A C T
Waste oils and fats (WOFs) are non-edible oils generated in amounts of more than 30 million and 10 million tons/year in China, respectively, from the production and consumption of cooking oil, and which would pollute the environment if disposed of improperly. Due to its poor quality, it is very difficult to transform WOFs to biodiesel by base catalyzed transesterification, especially when these have high free fatty acids and impurities. A new technology, sub-critical methanol alcoholysis process (SRCA process), was developed by SINOPEC Research Institute of Petroleum Processing for producing biodiesel from WOFs. The technical problems that were solved included how to dissolve WOFs in methanol, how to moderate the reaction conditions, how to transform WOFs into more biodiesel, and how to improve product quality. The first industrial demonstration unit of SRCA process with a scale of $60 \mathrm{kton} /$ year biodiesel was set up in 2009, and it had been operated continuously to produce biodiesel from soybean acid oil, palm acid oil, and cooking oil. The biodiesel product quality fulfil the requirements of National Standard (GB/T 20828-2007).
\end{abstract}

(C) 2013, Dalian Institute of Chemical Physics, Chinese Academy of Sciences. Published by Elsevier B.V. All rights reserved.

\section{Introduction}

Biodiesel is a liquid bio-fuel obtained from oils and fats. It has many of the properties of diesel, such as high cetane number and good lubricity, and it contains hardly sulfur and aromatic hydrocarbons. Biodiesel production is a new industry that has attracted much attention. In 2011, the production capacity was over 30 million tons, and the actual production was over 20 million tons in the world [1]. The Chinese government has paid much attention to biodiesel, and the "Medium and Long Term Development Plan for Renewable Energy" established in the 11th Five-Year Plan required the industrialization demonstration of biodiesel production by 2010, and for the capacity to reach 2 million tons per year by 2020 and to keep increasing after 2020.

The supply of oils and fats is a key need for the development of the biodiesel industry. Some previous works showed that the cost of the oils and fats can be $75 \%$ above in the biodiesel industry [2-4]. The total cost for energy, labor, and equipment depreciation is less than $15 \%$. In the West, edible oils, such as soybean oil, rapeseed oil, and palm oil, were used for biodiesel production in the beginning. In recent years, inedible oils and fats were investigated for reducing the cost. The USA has implemented some new policies to decrease the use of soybean oil for biodiesel, with tax abatement reaching \$306 per ton for using the waste oil as feedstock as compared with only \$153 per ton for using soybean oil [5].

China needs large amounts of edible oils because of the huge population, and its domestic production of plant oils is less than $40 \%$ of the demand, so that the remainder has to be obtained by importing transgenic soybean oil and edible palm oil [6]. Therefore, it is impossible in China to use edible oils and fats for producing biodiesel. The government has implemented a "trees and oil integration" project that uses tree fruit oil as

\footnotetext{
* Corresponding author. Tel: +86-10-82368237; Fax: +86-10-62311290; E-mail: duzexue.ripp@sinopec.com This work was supported by the National Basic Research Program of China (973 Program, 2012CB224803). DOI: 10.1016/S1872-2067(11)60490-7
} 
feedstock to be integrated with policies to encourage using waste oils and fats (WOFs) as the feedstock for biodiesel.

WOFs for biodiesel have become a popular research topic in recent years [7-12], which aims to solve the shortcomings of the liquid acid and base process. In the liquid acid and base process, the WOFs are pretreated by catalytic esterification and deacidification first. Then alkali catalytic transesterification is used, and the raw products are finally refined to a high quality biodiesel. However, problems exist because of the use of the inorganic acid and alkali catalysts, such as side reactions, serious corrosion, effluent discharge, and high cost. New techniques have been developed including strong solid acid or alkali catalysts [13], an enzymatic process [14], and the use of supercritical technology [15]. Research Institute of Petroleum Processing, SINOPEC has developed a sub-critical methanol alcoholysis (SRCA) technology. SRCA is applicable to a wide range of feedstocks, has high efficiency, is a cleaner process, and gives stable product quality. The demonstration industrial unit has run stably on a scale that reached 60000 tons per year. This is the first SRCA industrialization [16].

\section{Source and characteristics of WOFs}

\subsection{Source analysis of WOFs}

WOFs are produced in the processing of edible oils and meat products and in waste cooking oil, expired edible oils, acid oils, and inedible adipose. All these biomass are renewable resources. There are huge amounts of WOFs produced all over the world every year. For instance, the total plant oil yield in $2009 / 2010$ was 138.77 million tons [17] of which $20 \%-30 \%$ will become WOFs (over than 30 million tons) after processing and consumption [18]. If waste adipose is included, the WOFs yield would be much more. In China, the traditional Chinese dietary habits have resulted in much more oils being used for cooking and the efficiency of edible oil usage is lower than in western countries.

There are no official data of WOFs produced in China. We estimate that the annual WOFs yield is over 10 million tons in China from the following sources.

Cooking oil waste. Waste cooking oil mainly comes from hotels, restaurants, and daily use. No official data of waste cooking oil yield is available. We estimate this from the use efficiency of edible oil. In data reported by western countries, the use efficiency of edible oil is almost $75 \%$. That is, $25 \%$ of edible fats and oils will become WOFs. In 2011, the consumption of edible oil was 27.65 million tons [6], with 20 million tons from the food industry. The estimated WOFs yield is 5 million tons.

Expired oils. Some edible oils expire during storage, sale, and consumption. Moreover, inedible oil are produced during the cleaning of the oil tank. It is estimated that there is more than 1 million tons expired edible oils every year.

Animal fats. The Chinese breeding stocks of pig, cattle, sheep and duck rank first in the world. Much adipose is produced as a byproduct of meat production. On the basis of meat production data reported by the Statistics Bureau, in 2011, total meat pro-
Table 1

Estimated output of plant acid oils.

\begin{tabular}{lcccc}
\hline Sample & $\begin{array}{c}\text { Output } \\
\text { ratio } \\
(\%)\end{array}$ & $\begin{array}{c}\text { Output } \\
(\mathrm{kt})\end{array}$ & $\begin{array}{c}\text { Oil yield } \\
(\%)\end{array}$ & $\begin{array}{c}\text { Output of } \\
\text { acidification } \\
\text { oils (kt) }\end{array}$ \\
\hline Oil residue & $\sim 5$ & 1000 & 40 & 400 \\
Soap residue & $\sim 3$ & 600 & 80 & 480 \\
DD oil & $\sim 1$ & 200 & 90 & 180 \\
\hline
\end{tabular}

duction was 79.57 million tons in China. Using that $15 \%$ become byproduct, the yield of adipose was almost 12 million tons [19]. High quality adipose is used for cooking, as well as a raw material for the oil and fat chemical industries. The remaining inferior adipose, with a yield of almost 4 million tons, is not suitable for the oil and fat chemical industry due to an abnormal taste, and it is a good candidate feedstock for biodiesel.

Acid oil. Acid oil is a kind of high acid content oil produced by acidizing the oil scraps formed in the refining of crude plant oils to edible oils. These oil scraps consist of hydrated oil sediments, soap stock and deodorizer distillate oil (DD oil). 20.56 million tons crude plant oils are produced in China every year [6]. The detailed information is listed in Table 1. From Table 1, we deduce that all the oil scraps would form 1.06 million tons acid oil. Generally, acid oil is used for mixed fatty acid production. In recent years, mixed fatty acids are employed for making biodiesel. Thereby, this was used for the estimate of the amount of acid oil available for biodiesel production.

From the above analysis, the WOFs yield is over 10 million tons in China every year.

\subsection{Characteristics of WOFs}

The characteristics of WOFs are that these exist as various kinds, have a variety of sources and come from many different processes, and lack a uniform method of quality evaluation. In order to understand the characteristics of WOFs, and use these results to select processing technologies, hundreds of samples have been collected and analyzed in the past ten years. The experience showed that the present analytical methods for edible oils and fats are insufficient for WOFs analysis. It is very hard to completely identify the compositions of WOFs since there are numerous compounds in WOFs. Some compounds, like big molecules present in low amounts, are very sensitive to heat and light, and there is no effective method to analyze these. On the other hand, it is not important to identify the detailed compositions of WOFs because only saponifiable substances can be converted into biodiesel. Only the saponifiable substance content, acid value, moisture, solid particles, and other soluble glue impurities are enough to give the quality of the WOFs. The saponifiable substance content is a key index, and we have established special analysis methods for this. The characteristics of WOFs are listed in Table 2.

As shown in Table 2, the different of kinds of WOFs showed diverse characteristics. The quality of WOFs from China Hong Kong, China Macao, and Japan are superior to those from the 
Table 2

Quality characteristics of some different types of waste oils and fats.

\begin{tabular}{|c|c|c|c|c|c|c|}
\hline \multirow{2}{*}{ Species } & \multirow{2}{*}{ From } & \multirow{2}{*}{$\begin{array}{c}\text { Acid value } \\
\text { (mg KOH/g) }\end{array}$} & \multicolumn{4}{|c|}{ Mass content (\%) } \\
\hline & & & Saponifiable matter & Moisture & Solid impurity & Colloid impurity \\
\hline Soybean acid oil & Huzhou, Zhejiang, China & 139.7 & 93.6 & 1.9 & 0.3 & 4.2 \\
\hline Cotton acid oil & Handan, Hebei, China & 126.4 & 83.7 & 2.2 & 0.6 & 13.5 \\
\hline Rape acid oil & Yueyang, Hunan, China & 108.3 & 89.2 & 2.5 & 0.5 & 7.8 \\
\hline Rice acid oil & Wuhan, Hubei, China & 119.5 & 78.4 & 1.8 & 1.9 & 17.9 \\
\hline Palm frying oil & Beijing, China & 6.5 & 97.8 & 0.2 & 0.5 & 1.5 \\
\hline Cotton frying oil & Shihezi, Xinjiang, China & 7.6 & 95.5 & 0.3 & 0.5 & 3.7 \\
\hline Frying hydrogenated oil & Beijing, China & 4.5 & 98.5 & 0.2 & 0.7 & 0.6 \\
\hline Cooking oil-1 & Beijing, China & 28.4 & 93.9 & 2.3 & 1.0 & 2.8 \\
\hline Cooking oil-2 & Jinzhou, Hebei, China & 78.9 & 94.3 & 3.2 & 0.4 & 2.1 \\
\hline Cooking oil-3 & Guangzhou, Guangdong, China & 16.8 & 95.1 & 1.9 & 0.2 & 2.8 \\
\hline Cooking oil-4 & Shanghai, China & 59 & 94.7 & 2.6 & 0.5 & 2.2 \\
\hline Cooking oil-5 & Hong Kong, China & 5.2 & 97.9 & 0.7 & 0.1 & 1.5 \\
\hline Cooking oil-6 & Macao, China & 6.4 & 96.6 & 0.9 & 0.3 & 2.2 \\
\hline Cooking oil-7 & Japan & 3.7 & 98.9 & 0.3 & 0.2 & 0.6 \\
\hline Palm fatty acid distillate & Malaysia & 177.6 & 99.1 & 0.6 & - & 0.3 \\
\hline
\end{tabular}

mainland of China, which was attributed to the garbage classification used in these places. The acid values of these WOFs are relatively lower, and they can be treated by alkali catalytic transesterification after deacidification and degumming. Hence, alkali catalytic transesterification is still used in Japan for making biodiesel from cooking WOFs.

\subsection{Utilization of WOFs and its significance as an energy resource}

The characteristics of WOFs, such as its abundance and diversity and diffused origins make them a potential environment pollution source [20]. When WOFs get into soil, they would form an oil membrane on the surface of soil particles, which results in an anaerobic soil. The anaerobic condition hinders the activities of microbes and the WOFs that surround plant roots impede the absorption of nutrients. WOFs can also cause great harm in water. The oil and fat can easily adhere to drain pipes and can block the pipes. WOFs can also contaminate water, causing pollution to water resources. Water polluted by WOFs shows a high value of chemical oxygen demand (COD), biochemical oxygen demand (BOD), and suspended substance (SS), which indicates high oxygen consumption in the water during degradation. Meanwhile, the oil film can prevent oxygen dissolving into the water, which would lead to the death of fishes and aquatic plants, accompanied with the releasing of effluvial gases.

WOFs have been used as additives of animal feed and detergents, but recent studies showed that this can be harmful to human beings. Subsequent treatment to remove these is difficult and expensive [21]. Nowadays, the resource utilization of WOFs has attracted much attention. It has been identified as a substitute for petroleum. Japan has achieved a scale of $400 \mathrm{kt}$ per year of biodiesel production from waste frying oil. This would reduce environment pollutions which might otherwise be caused by WOFs, and it also generates a clean and renewable biofuel [22].

Using WOFs for biodiesel production is the best way to use WOFs. The several reasons are summarized as follows: (1)
WOFs are available all year without the capital cost of growing oil trees; (2) the quality requirements of WOFs for biodiesel production are not so stringent as for producing chemical products, and almost all kinds of WOFs can be used for biodiesel production; (3) the raw material cost is low because the price of WOFs is less than $70 \%$ of edible oil; (4) biodiesel as a substitute of diesel is a promising prospect in the domestic market.

In China in the present conditions, the use of WOFs for biodiesel is suitable. The Chinese government highly supports biodiesel production from WOFs to avoid using edible fats and oils for biodiesel. This would make the waste valuable, and also prevent WOFs from being used for cooking. The developing of the WOFs biodiesel industry will lay a foundation for the tree oils biodiesel industry. Although "trees and oils integration" is a policy for the biodiesel industry advocated by the Chinese government, it has some problems. In the early stage, the long growth cycle of plants would limit productivity because of the inadequate supply of the feedstock. If this cause a slowdown in the development of the biodiesel industry, there would be poor sale when the plants become available. This would dampen the enthusiasm of the planting industry. Consequently, the WOFs biodiesel industry should be first developed. Then, this would lead to a demand for early harvest plants, which would benefit the planting industry. When the planting yield becomes stable, new biodiesel production plants can be built to promote the "trees and oils integration" policy.

\section{Some key technical points of the SRCA process}

Biodiesel production from WOFs was industrialized in 2002 by developing the traditional alcoholysis catalyzed by acid and base $[23,24]$. On account of the high acid value of WOFs, an acid catalyst is first used to decrease the acid value by esterification. Then, the inorganic acid catalyst is removed. Finally, a strong base catalyst is used for the transesterification to form the fatty acid methyl ester. Due to consideration of the cost and the materials of the facility, sulfuric acid and sodium hydroxide are the commonly used catalysts. This process is mild and easy in op- 
eration, but it is accompanied by some difficult problems during production. When sulfuric acid is used as the catalyst for acidolysis, 90\% free fatty acids (FFAs) are converted in $60 \mathrm{~min}$, and the last $10 \%$ needs another $120 \mathrm{~min}$. However, extending the reaction time has serious consequences, such as side reactions and acid corrosion of the apparatus. Therefore, the use of a solid acid to replace sulfuric acid has been suggested, but the short lifetime of the solid acid has hindered its industrialization $[25,26]$. NaOH can achieve good performance, but saponification side reactions induced by $\mathrm{NaOH}$ decrease the yield of biodiesel; also, it easily deposits on the inner surface of the heat exchanger and decrease heat exchange efficiency. The saponification which occurs during the washing process can cause loss of the product. Too much saponification will result in the emulsification of biodiesel and water, and the production cannot be maintained continuously.

The defects of the acid-base method, such as low productivity, corrosion, and environment pollution are caused by using an inorganic strong acid. The only way to solve these problems is to develop a new technology that does not need an acid or base catalyst. This was the motivation for why the supercritical alcoholysis technique was chosen. In a previous report, the high conversions obtained were based on severe reaction conditions. For example, the temperature was over $350{ }^{\circ} \mathrm{C}$, the pressure was $19 \mathrm{MPa}$, and the molar ratio of methanol and oil was 42 . The high temperature and pressure would need more investment for the apparatus, and the high molar ratio of methanol and oil needs more energy during methanol recycle. Hence, there is a need for mild reaction conditions accompanied by a high yield to make the supercritical alcoholysis technology acceptable and significant. The SRCA process has solved many key problems, and it is now a successful industrial demonstration.

\subsection{Dissolution of methanol and oils}

It is widely accepted that oils are insoluble in methanol, which is a barrier for their reactions. Stirring and using a cosolvent can promote the mixing of methanol and oils. Under supercritical methanol conditions, stirring can cause problems with leaks under high pressure. Furthermore, much more energy is consumed by stirring. Thereby, it is crucial to control the methanol-oil phase equilibrium during the process of heating and pressuring methanol to the supercritical state. Our research on this was initiated in 2003 and was published in 2006 [23]. After that, some other related works were reported. Shimoyama et al. [33-36] focused on the gas-liquid equilibrium and liquid-liquid equilibrium of the methyl ester-methanol and byproduct glycerol-methanol systems under supercritical methanol conditions. The temperature range was from 220$270{ }^{\circ} \mathrm{C}$, and at $300^{\circ} \mathrm{C}$, the range of pressure was from 2.16 to 8.78 MPa with a peak value of $11.45 \mathrm{MPa}$. Hegel et al. [37,38] studied the phase behavior of the mixture system before and after reaction under supercritical methanol conditions. When propane was used as a cosolvent, the range of temperature and pressure was $270-315^{\circ} \mathrm{C}$ and 7-21.1 MPa, respectively. Glisic et al. [39] studied the effects of the gas-liquid equilibrium be- havior of the sunflower seed oil-methanol system on conversion. The ranges of temperature and pressure were $200-230{ }^{\circ} \mathrm{C}$ and 2.9-5.6 MPa, respectively. At that time, our target was Canola oil and we studied the methanol-Canola oil system and its phase equilibrium before reaction during heating and pressuring. Under high temperature and pressure $\left(>240{ }^{\circ} \mathrm{C},>8.0 \mathrm{MPa}\right)$, methanol easily reacts with oils, such that the composition of the system is changing and the situation becomes too complex to analyze. Hence, the chosen ranges of temperature and pressure were $80-200{ }^{\circ} \mathrm{C}$ and $4.0-10.0 \mathrm{MPa}$, respectively. The results showed that under these conditions and without a catalyst, the reaction can be ignored during the equilibrium time. The Dohrn and Brunuer's rule can be used, and from it and the liquid molar volume and molar volume, data for the phase equilibrium can be calculated from the critical properties of triglyceride and the corresponding fatty acid. The data for the phrase equilibrium of methanol and oils over a wide range can be predicted by fitting the state equation. We used equations suitable for a high pressure system, such as the Peng-Robinson (PR) and Redlich-Kwong-Aspen (RKA) equations. After the input of the phrase equilibrium data for the methanol-oil system into the Aspen Plus ${ }^{\circledR} 10.1$ simulation system, the binary interaction parameters and polarity factor were obtained by fitting. The mean deviations between the calculated and experimental values were $1.73 \%$ and $0.30 \%$, and the maximum deviations were $13.63 \%$ and $4.44 \%$, respectively. The results showed that increasing the temperature favors oils dissolution, but the dissolution behavior of oils in methanol versus pressure is very complicated. As shown in Fig. 1, when the temperature is lower than $150{ }^{\circ} \mathrm{C}$, at the same temperature, increasing pressure results in decreasing the solubility of methanol in canola oil, and when the temperature is over $150{ }^{\circ} \mathrm{C}$ and pressure is over 8.0 $\mathrm{MPa}$, increasing temperature and pressure favor the solubility of methanol in canola oil. From Fig. 1, we can see that when the system is above the methanol critical point, the solubility of methanol in canola oil is independent of temperature and pressure. On this basis, we can also predict the phrase equilibrium data in a broad range by fitting of the state equation. Combining the composition changes after reaction with the effects of phrase equilibrium is helpful for understanding the supercritical alcoholysis reaction in the methanol-oil system. It is also useful for optimizing the reaction pressure.

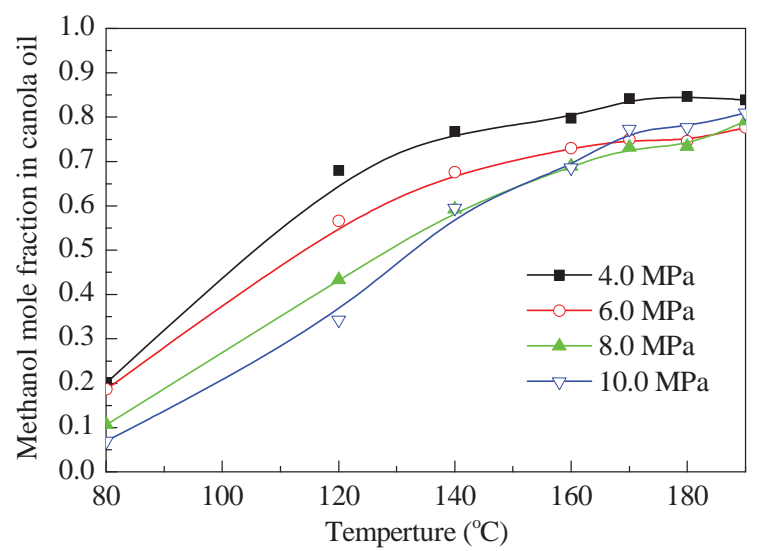

Fig. 1. Solubility of methanol in Canola oil. 
The aim of introducing a cosolvent into the methanol and oil in the supercritical methanol condition system is to promote methanol and oil mutual dissolution, which promotes the reaction and increases the yield of biodiesel. The cosolvent chosen included $n$-hexane, cyclohexane, $n$-heptane, biodiesel, ethyl acetate, and butyl acetate. In order to avoid disturbance by impurities in the WOFs, a relatively high quality hydrogenated oil was chosen as the raw material. The conditions were $300{ }^{\circ} \mathrm{C}$ and $12 \mathrm{MPa}$, the mass ratio of alcohols and oil was 0.66 , and the reaction time was $300 \mathrm{~min}$. The results showed that a cosolvent can increase the yield by nearly $20 \%$. On the other hand, different cosolvents led to different results. When esters compounds were in low amounts, the results were better for them than for alkanes, but the results for short carbon chain esters were a little poor when the content of cosolvent was increased.

From a solvent separation experiment, it was found that the volume and composition of the alkane remained the same. However, the volume of short carbon chain esters decreased, and the compositions in the mixture changed with methyl acetate as well, which showed the stability of alkane solvents, and that short carbon chain esters were unsuitable as cosolvents due to their reactions.

The above results showed that adding a cosolvent promoted the reaction to a certain extent, but the yield was still lower than $80 \%$. Furthermore, the added solvent has to be separated after reaction. This will cause an increase in energy consumption. Therefore, adding a cosolvent is not a good solution for the mutual dissolution of methanol and oils. We were inspired by the latter tests to obtain a better solution without any cosolvent. The effect of time on oil conversion is shown in Table 3. The reaction time was obtained from the effective volume of reactor divided by the volume of oil that was injected every minute. We can see that the samples taken at different times show different phenomena during settlement stratification. The samples from short times and long times were separated into two layers, but with different compositions. The sample from $5 \mathrm{~min}$ has a top methanol layer and an oil bottom layer. The sample from 30 min has a top oil layer and a glycerol bottom layer. When the reaction times were 10 and $15 \mathrm{~min}$, the samples were uniform, which is an ideal result for studying the cosolvent.

Using the results in Table 3, we used the oil sample reacted for 10 and $15 \mathrm{~min}$ for the further experiments. The results are shown in Fig. 2. We can see that the oils showed some difference between the two samples in the first $20 \mathrm{~min}$, and that after $30 \mathrm{~min}$, the yield increased very little with increasing reaction time. This meant that the reaction has reached equilibrium. Under the same conditions, the conversion from the uniform sample was clearly better than that obtained by the promotion by the cosolvent, and the yield was increased $10 \%$ to reach

Table 3

Effect of reaction time on the yield of biodiesel and phase separation.

\begin{tabular}{ccc}
\hline Reaction time (min) & Yield (\%) & Phase separation \\
\hline 5 & 11.5 & two phase: $\mathrm{MeOH}$, oil \\
10 & 28.5 & homogeneous \\
15 & 38.7 & homogeneous \\
30 & 57.9 & two phase: oil, glycerine \\
\hline
\end{tabular}

Other conditions: $300{ }^{\circ} \mathrm{C}, 12 \mathrm{MPa}, m_{\mathrm{MeOH}} / m_{\text {oil }}=0.66$.

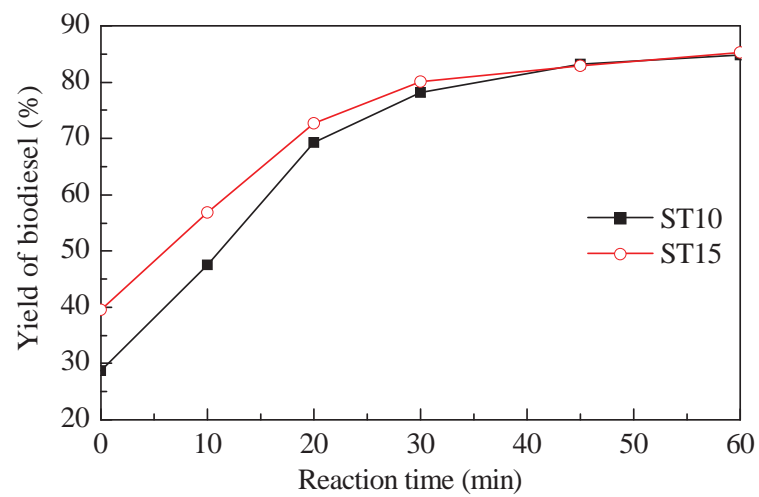

Fig. 2. Effect of reaction time on the yield of biodiesel with ST10 and ST15 as feedstocks. Reaction conditions: $300{ }^{\circ} \mathrm{C}, 12 \mathrm{MPa}, m_{\mathrm{MeOH}} / m_{\mathrm{oil}}=$ 0.66 .

almost $85 \%$.

The chemical compositions of ST10 and ST15 are shown in Table 4. The ST10 and ST15 samples are mixtures of triglyceride (TG), FFA, and intermediate products diacylglycerol (DG), monoglyceride (MG), and products fatty acid methyl ester (FAME) and methanol. From the molecular structure analysis, DG, MG, and FAME can undergo fibrinolysis, especially DG and MG with a nonpolar long fatty acid chain and strong polar glycerol group. This is an ideal structure for a cosolvent. It is to be noted that these are not additives but intermediate products, which react with methanol to form products. In addition, the separation process is not needed in this method.

From a further study, the solving of the mutual solubility in the system was confirmed by controlling of the reaction, and the design of an integrated device that integrated materials heating and pre-reaction. The results proved that the device designed achieved the intended aim.

The number of reports on the cosolvent increased after 2005 , and included propane [30,39], $\mathrm{CO}_{2}$ [40], and $n$-hexane $[29,41]$. The aims of using $\mathrm{CO}_{2}$ and propane were to reduce the severity of the operation conditions, but the yield decreased with decreasing alcohol/oil ratio and temperature. The pressure can be slightly decreased without decreasing conversion. Using $n$-hexane can give decreases in the temperature and pressure. For example, the temperature and pressure can be decreased to $280{ }^{\circ} \mathrm{C}$ and $10 \mathrm{MPa}$, respectively, but the ratio of alcohol and oil has to be increased to keep the conversion.

\subsection{How to achieve good reaction results under subcritical methanol conditions}

The most important reaction conditions for the technology of alcoholysis in a supercritical methanol system are the reaction temperature, ratio of methanol and oil, and reaction time.

Table 4

Chemical mass constitution of ST10 and ST15.

\begin{tabular}{lccccccccc}
\hline & \multicolumn{6}{c}{ Chemical mass constitution (\%) } \\
\cline { 2 - 9 } Sample & TG & DG & MG & FAME & FFA & MeOH & $\begin{array}{c}\text { Mois- } \\
\text { ture }\end{array}$ & $\begin{array}{c}\text { Solid } \\
\text { impurity }\end{array}$ & $\begin{array}{c}\text { Gum } \\
\text { impurity }\end{array}$ \\
& & & & & & & 0.2 & 0.4 & 0.4 \\
ST10 & 29.9 & 3.8 & 8.9 & 17.8 & 1.8 & 36.8 & 0.2 & 0.5 & 0.4 \\
ST15 & 20.1 & 3.3 & 7.8 & 24.1 & 1.9 & 35.6 & 0.3 & 0.4 \\
\hline
\end{tabular}


High temperature, high pressure, high methanol/oil ratio, and short reaction time used to be necessary for the technology and a high conversion rate [42-45]. But using any one of these would lead to increasing cost. Reducing the severity of the reaction conditions means to reduce the reaction temperature, pressure, and methanol/oil ratio. So, reducing the severity of the reaction conditions but without decreasing the production yield is the key to the development of the SRCA technology.

Theoretically, under the condition of sub/supercritical methanol, the different partial molar volumes can change the equilibrium constant. Furthermore, the reaction rate would be increased because of the increase of the mass transfer and diffusion rates. The improved reaction between TG and FFA can be attributed to the changed equilibrium constant and increased reaction rate [46]. A series of reaction equilibrium constants of alcoholysis in the sub/supercritical methanol system have been calculated in the references and NIST database $\left(K^{0}{ }_{298}=4.485 \times 10^{9} ; K^{0}{ }_{573}=24.292\right)$. These showed that $\mathrm{a}$ high temperature goes against the increasing of the equilibrium conversion. Therefore, the reaction of alcoholysis in the supercritical methanol system is an exothermic reaction [47].

Research on the kinetics showed that [47] above the critical methanol temperature and pressure, the methanol and oil needed no catalyst for the alcoholysis reaction in a continuous flow tubular reactor. There are three steps in this process. DG and $\mathrm{MG}$ are intermediate products. The alcoholysis reaction in the temperature range of $250-350{ }^{\circ} \mathrm{C}$ would be the rate determining step after the solving of the problem of methanol and oil miscibility. The relationship between the equilibrium constant $(k)$ and temperature $(T)$ of each step can be obtained by the iterative solution of the reaction rate equation (differential equation). The results (Fig. 3) showed that the $\ln k$ versus $1 / T$ curves were not linear. So, the reaction mechanisms of alcoholysis in supercritical methanol are different from the proposed ones. The calculated reaction rate constants of each alcoholysis step, which were obtained from the experimental data, can only give the macroscopic reaction rate during a certain period. The activation energy of each step (including the forward and backward reactions, Table 5) was obtained by the fitting of Fig. 3. This showed that the activation energies of these steps were in the range of $15-80 \mathrm{~kJ} / \mathrm{mol}$. This result is

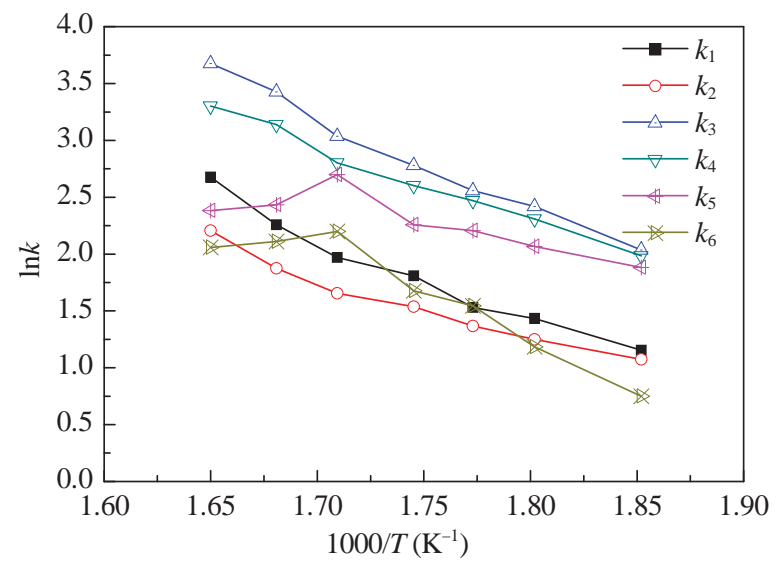

Fig. 3. Arrhenius plot of TG alcoholysis in sub/super-critical methanol.
Table 5

Activation energy $\left(E_{\mathrm{a}}\right)$ of TG alcoholysis in sub/super-critical methanol.

\begin{tabular}{lcc}
\hline \multirow{2}{*}{ Reaction course } & \multicolumn{2}{c}{ Activation energy $E_{\mathrm{a}}(\mathrm{kJ} / \mathrm{mol})$} \\
\cline { 2 - 3 } & This work [47] & Ref. [48]* \\
\hline $\mathrm{TG} \rightarrow \mathrm{DG}$ & $65.45-81.66$ & 55.02 \\
$\mathrm{DG} \rightarrow \mathrm{TG}$ & $28.88-49.81$ & 41.55 \\
$\mathrm{DG} \rightarrow \mathrm{MG}$ & $67.13-81.86$ & 83.09 \\
$\mathrm{MG} \rightarrow \mathrm{DG}$ & $40.78-53.44$ & 61.25 \\
$\mathrm{MG} \rightarrow \mathrm{GL}$ & $15.41-29.61$ & 26.11 \\
$\mathrm{GL} \rightarrow \mathrm{MG}$ & $39.24-70.38$ & 41.12 \\
\hline
\end{tabular}

* Reaction catalyzed by base catalyst.

different from that reported in the references under atmospheric alkaline catalytic conditions [48]. However, the activation energy of the second step (DG transfer into MG) for no catalyst alcoholysis under the condition of supercritical methanol was close to that under the alkaline catalytic conditions. This means that the alcoholysis of DG does not need to overcome a high reaction energy barrier regardless of the use of a catalyst or not. The activation energies of the second and third steps were different from those under the alkaline catalytic conditions. Therefore, we suggested that the alcoholysis reactions of methanol and DG play important roles in the whole reaction. There have been some reports on the kinetics of TG alcoholysis under the condition of supercritical methanol [43,49-51]. Most of these used batch reactors, which simplify the reaction mechanism and kinetics rate equation. The results have some value as references for the reaction. However, these have some relatively larger deviations from the actual reaction process.

The research on the chemical thermodynamics and kinetics described above showed that increasing temperature goes against a high reaction conversion. Adjusting the temperature to get the necessary reaction rate is enough for the technology. The key to increasing the conversion is to provide the appropriate reaction condition for the generation of the intermediate product, which is generated by the reaction between methanol and TG. For the WOFs, both the conversion of FFA and its influence on TG conversion should be considered.

A series of WOFs reaction conversions were investigated under different temperature, pressure, and methanol/oil ratio. The WOFs included bean acid oil, palm acid oil, frying palm oil, hydrogenated frying oil, cooking oil and PFAD (Fig. 4). For the hydrogenated frying oil with a low acid value, the yield of biodiesel increased with increasing temperature $\left(220{ }^{\circ} \mathrm{C}, 70 \%\right.$; $350{ }^{\circ} \mathrm{C}, 90 \%$ ). But for the high acid value oil, the yield of biodiesel has a peak value in the range of $260-300{ }^{\circ} \mathrm{C}$. Above 300 ${ }^{\circ} \mathrm{C}$, it was found that a higher acid value gave a faster drop in the yield. However, above the critical pressure of methanol, there was no obvious change of biodiesel yield with increasing pressure. The biodiesel yield also can be increased by raising the methanol/oil ratio. But above the ratio of 0.88 (equal to methanol/oil molar ratio $=24: 1$ ), more methanol would lead to a slow increase in biodiesel yield.

From the research above, considering the influence of the acid value, increasing the temperature and pressure can improve the production from low acid value materials, for example palm frying oil and hydrogenated frying oil. For an oil with a 


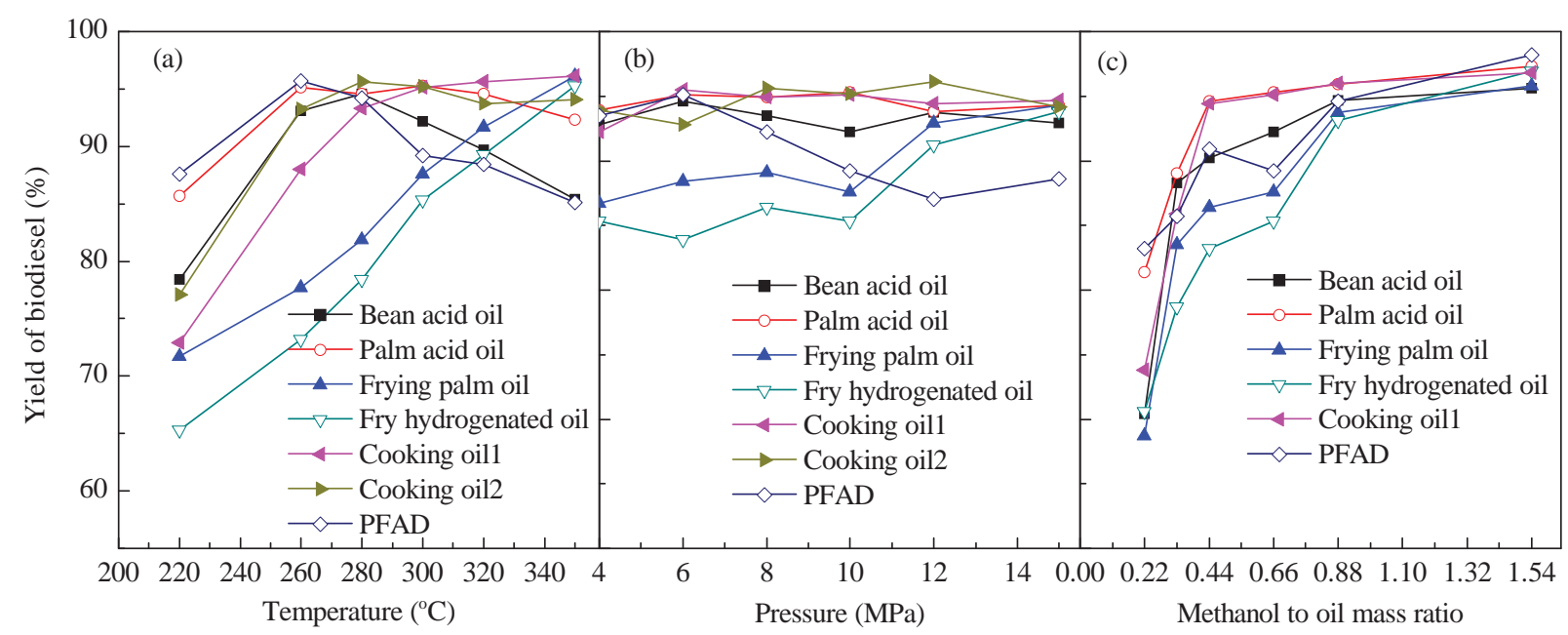

Fig. 4. Effect of temperature (a), pressure (b), and methanol to oil mass ratio (c) on biodiesel yield. Reaction conditions: $(\mathrm{a}) 12 \mathrm{MPa}, m_{\mathrm{MeOH}} / M_{\mathrm{oil}}=0.66$, $30 \mathrm{~min}$; (b) $300{ }^{\circ} \mathrm{C}, \mathrm{m}_{\mathrm{MeOH}} / M_{\mathrm{oil}}=0.66,30 \mathrm{~min}$; (c) $300^{\circ} \mathrm{C}, 12 \mathrm{MPa}, 30 \mathrm{~min}$.

high acid value, there is a peak value of biodiesel yield when the temperature and pressure were increased, and further increasing of the temperature and pressure would decrease the production yield, especially for the PFAD. This means that the biodiesel yield from different acid value materials would be different under the same conditions. So, adjusting of the acid value can be an effective way to get a high biodiesel yield under mild reaction conditions.

Under mild conditions (260-280 ㄷ, 6-8 MPa, methanol/oil: 0.44-0.88), a better conversion can be obtained from a higher acid value of the reactants (> $50 \mathrm{mg} \mathrm{KOH} / \mathrm{g}$ ) [16]. If the acid value of biomass with a low acid value was increased to $50 \mathrm{mg}$ $\mathrm{KOH} / \mathrm{g}$ or above by adding a high acid value oil or fatty acid, there can be better conversion. The biodiesel yield can be almost $95 \%$.

The results above indicated that fatty acid not only can allow milder reaction conditions, but also promote the conversion of TG. It seemed that the fatty acid has the role of a catalyst in the reaction process, which has been reported in a previous research [52]. However, in our opinion, it is difficult for fatty acid to act as a catalyst. The transesterification of TG can be catalyzed either by an acid or a base catalyst. But their reaction mechanisms are different. Under alkaline condition, the alkali reacted with methanol to form methoxy ions. Then, the methoxy ions attack the TG molecule. This step greatly shortens the required reaction time. So, using a base catalyst is an effective way for this reaction. On the other hand, under acidic condition, $\mathrm{H}^{+}$is first obtained from the ionization reaction of TG. Second, $\mathrm{H}^{+}$combines with oxygen of the acyl group in the TG molecule to form the active intermediate. Then, the active intermediate reacts with methanol. There are two main limits during these steps: one is the extent of the ionization and the other is the large steric hindrance of the active intermediate, which makes it difficult for it to attack the methanol molecule. Therefore, transesterification under acidic condition always needs a long reaction time. Fatty acids are large molecules. The $\mathrm{H}^{+}$concentration is very low in methanol due to the low extent of ionization of the fatty acid molecule. So, we conclude that it is difficult for a fatty acid to act as a catalyst in this reaction.

The water generated from FFA transesterification is actually the catalyst in this reaction. Under the supercritical methanol condition, the dissociation of methanol is enhanced and generates methoxy ions. At the same time, the supercritical methanol also combines with proton to form the corresponding proton compound. Both these promote active intermediate generation and the reaction between TG and FFA. The reaction time is much shortened. The reaction mechanism in supercritical methanol is quite different from those under acidic or alkaline catalyst conditions.

However, the association and dissociation of supercritical methanol are contradictions. Before dissociation, the associated methanol has to first break the association to get to the isolated molecule form. Under high pressure, the high local density of methanol as well as the high methanol/oil molar ratio can promote the association. But a high temperature favors dissociation. In addition, water also can influence the association equilibrium. Water can more easily combine with methanol because of its strong polarity. Then, the methanol association is broken. This process promotes methanol dissociation and generates more active group. As compared with TG, FFA has less steric hindrance. So, if both TG and FFA existed in the raw material oil, the active group from methanol dissociation would more easily combine with FFA to form fatty acid methyl ester and water. The generated water breaks the association equilibrium of methanol. Meanwhile, it combines with $\mathrm{H}^{+}$and then attacks the TG molecule. TG will then be hydrolyzed into fatty acid. Therefore, fatty acid methyl ester generation from TG is promoted indirectly. Kusdiana et al. [53] has reported this. They suggested that the water in supercritical methanol has the function of a catalyst. Its acidity is stronger than that of methanol, which is good for TG alcoholysis. However, it cannot increase the methyl ester yield.

\subsection{Industrial demonstration of SRCA technology}

The first industrial demonstration plant of the SRCA tech- 
Table 6

Run results of the SRCA industrial demonstration unit.

\begin{tabular}{|c|c|c|c|c|c|c|c|c|}
\hline \multirow[b]{2}{*}{ Feedstock } & \multicolumn{5}{|c|}{ Mass property } & \multirow[b]{2}{*}{$\begin{array}{l}\text { Temperature } \\
\left({ }^{\circ} \mathrm{C}\right)\end{array}$} & \multirow[b]{2}{*}{$\begin{array}{c}\text { Pressure } \\
\text { (MPa) }\end{array}$} & \multirow[b]{2}{*}{$\begin{array}{l}\text { Yield } \\
(\%)\end{array}$} \\
\hline & $\begin{array}{c}\text { Acid value } \\
(\mathrm{mg} \mathrm{KOH} / \mathrm{g})\end{array}$ & $\begin{array}{c}\text { Saponifiable } \\
\text { matter content (\%) }\end{array}$ & Moisture (\%) & $\begin{array}{c}\text { Solid } \\
\text { impurity (\%) }\end{array}$ & $\begin{array}{c}\text { Colloid } \\
\text { impurity }(\%)\end{array}$ & & & \\
\hline Soybean acid oil & 140.3 & 88.0 & 1.7 & 0.4 & 5.0 & 260 & 6.0 & 95.3 \\
\hline Palm acid oil & 96.6 & 92.7 & 1.4 & 0.3 & 1.3 & 260 & 6.0 & 96.7 \\
\hline Cooking oil & 4.3 & 94.8 & 3.7 & 0.9 & 2.7 & 280 & 6.5 & 94.7 \\
\hline
\end{tabular}

Other conditions: oil feed $7.35 \mathrm{t} / \mathrm{h}$, methanol feed $3.2 \mathrm{t} / \mathrm{h}$, time $1 \mathrm{~h}$.

nology was built in 2009. Its scale was 60000 tons per year. The feedstock included bean acid oil, palm acid oil and cooking oil. The properties of the raw materials and process conditions are shown in Table 6.

The test results of the products from this industrial demonstration met all the needs of GB/T 20828.

\section{Conclusions}

The use of WOFs to produce biodiesel is the best way to avoid environment pollution caused by WOFs. Critical state methanol technology is suitable for producing biodiesel from WOFs, but severe reaction temperature, pressure and methanol/oil ratio would increase production cost. Research on the thermodynamic phase equilibrium of the methanol-oil system indicated that when the temperature and pressure were lower than of critical methanol, increasing the temperature helped methanol dissolution in oil, which is opposite to the effect of pressure. When the temperature and pressure are higher than that of critical methanol, methanol dissolution in oil is no longer influenced by changes in these. Adding the reaction intermediates of MG and DG can promote the mutual dissolution of methanol and oil, and promote the further conversion of raw oil and increase the yield of biodiesel under sub/supercritical methanol conditions. Research on the reaction kinetics of oil alcoholysis in critical methanol indicated that the alcoholysis reaction of methanol and oil is carried out in three steps. The intermediates include DG and MG. The key step is the reaction of DG and methanol to generate MG. Increasing temperature, pressure and methanol/oil ratio are not always suitable for increasing the WOFs conversion to biodiesel, and increasing the acid value of the feedstock can be more effective for increasing WOFs conversion to biodiesel. This is because the water from the reaction between methanol and free fatty acid can catalyze the alcoholysis of TG. The SRCA biodiesel process developed has a successful industrial demonstration. The acid value of the biodiesel produced in the demonstration plant met the needs of GB/T 20828 ( $\leqslant 0.8 \mathrm{mg} \mathrm{KOH} / \mathrm{g}$ ). However, both the standards of the West and the new standard of China require a lower acid value ( $\leqslant 0.5 \mathrm{mg} \mathrm{KOH} / \mathrm{g}$ ). The upgrading of the standards is a challenge for SRCA process development and will determine the direction of future technology research.

\section{References}

[1] Atabani A E, Silitong A S, Badruddin I A, Mahlia T M I, Masjuki H H, Mekhilef S. Renew Sustain Energy Rev, 2012, 16: 2070

[2] Ahmad A L, Mat Yasin N H, Derek C J C, Lim J K. Renew Sustain En- ergy Rev, 2011, 15: 584

[3] Lin L, Zhou C Sh, Vittayapadung S, Shen X Q, Dong M D. Appl Energy, 2011, 88: 1020

[4] Ragit S S, Mohapatra S K, Kundu K, Gill P. Biomass Bioenergy, 2011, 35: 1138

[5] Min E Z, Du Z X. Chin Eng Sci (闵恩泽, 杜泽学. 中国工程科学), 2010, 12(2): 1

[6] Wang R Y. China Oils Fats (王瑞元. 中国油脂), 2012, 37(6): 1

[7] Bankovic-Ilic I B, Stamenkovic O S, Veljkovic V B. Renew Sustain Energy Rev, 2012, 16: 3621

[8] Shin H-Y, Lee S-H, Ryu J-H, Bae S-Y. J Supercritical Fluids, 2012, 61: 134

[9] Patil P, Deng Sh G, Rhodes J I, Lammers P J. Fuel, 2010, 89: 360

[10] Math M C, Kumar S P, Chetty S V. Energy Sustain Develop, 2010, 14: 339

[11] Lu H F, Shi G Q, Liu Y Y, Liang B. Chem Ind Eng Progr (鲁厚芳, 史国 强, 刘颖颖, 梁斌. 化工进展), 2011, 30(1): 126

[12] Wang T, Xie W L, Li H, Wang Y B. China Oils Fats (王涛, 谢文砧, 李 会，王迎宾. 中国油脂), 2010, 35(5): 48

[13] Kawashima A, Matsubara K, Honda K. Bioresource Technol, 2008, 99: 3439

[14] Fukuda H, Hama S, Tamalampudi S, Noda H. Trends Biotechnol, 2008, 26(12): 668

[15] Sawangkeaw R, Bunyakiat K, Ngamprasertsith S. J Supercrit Fluids, 2010, 55: 1

[16] Du Z X, Wang H J, Jiang Y Sh, Chen Y F, Min E Z. Acta Petrol Sin (Petrol Process Sect) (杜泽学, 王海京, 江雨生, 陈艳凤, 闵恩泽. 石油学报 (石油加工)), 2012, 28(3): 353

[17] Wang R Y. China Oils Fats (王瑞元. 中国油脂), 2011, 36(6): 1

[18] Yao Zh L, Min E Z. Natural Gas Industry (姚志龙, 闵恩泽. 天然气工 业), 2010, 30(5): 123

[19] National Bureau of Statistic of China. National Statistics Report 2011 (中国国家统计局. 2011年度统计公报), 2012-2-22

[20] Li H Y. [MS Disserttation]. Tianjin: Tianjin S\&T Univ (李慧暳. [硕士 学位论文]. 天津: 天津科技大学), 2004

[21] Lü F, He P J, Shao L M. Techniq Equipment Environ Pollution Control (吕凡, 何品晶, 邵立明. 环境污染治理技术与设备), 2006, 7(2): 9

[22] Zhang J. Renew Energy Resources (张瞕. 可再生能源), 2009, 27(1): 117

[23] Ye H D, Ding Y D (叶活动, 丁以钿). CN 1382 762. 2002

[24] Yu J Q, Chen D Y, Li J X, Chen Z D (俞建秋, 陈德裕, 李俊雄, 陈自 端). CN 1473 907.2004

[25] Li N, Zhao H, Li H P, Wang F Sh. Ind Catal (李娜, 赵华, 李会鹏, 王 福帅. 工业催化), 2012, 20: 7

[26] Jacobson K, Gopinath R, Meher L C, Dalai A K. Appl Catal B, 2008, 85: 86

[27] Tan K T, Lee K T. Renew Sustain Energy Rev, 2011, 15: 2452

[28] Tan K T, Lee K T, Mohamed A R. Fuel Process Technol, 2011, 92: 1905

[29] Tan K T, Lee K T, Mohamed A R. J Supercrit Fluids, 2010, 53: 88

[30] Cao W L, Han H W, Zhang J Ch. Fuel, 2005, 84: 347

[31] Fauzi A H M, Amin N A S. Renew Sustain Energy Rev, 2012, 16: 


\title{
Graphical Abstract
}

Chin. J. Catal., 2013, 34: 101-115 doi: 10.1016/S1872-2067(11)60490-7

\section{Research and development of a sub-critical methanol alcoholysis process for producing biodiesel using waste oils and fats}

DU Zexue*, TANG Zhong, WANG Haijing, ZENG Jianli, CHEN Yanfeng, MIN Enze

Research Institute of Petroleum Processing, SINOPEC

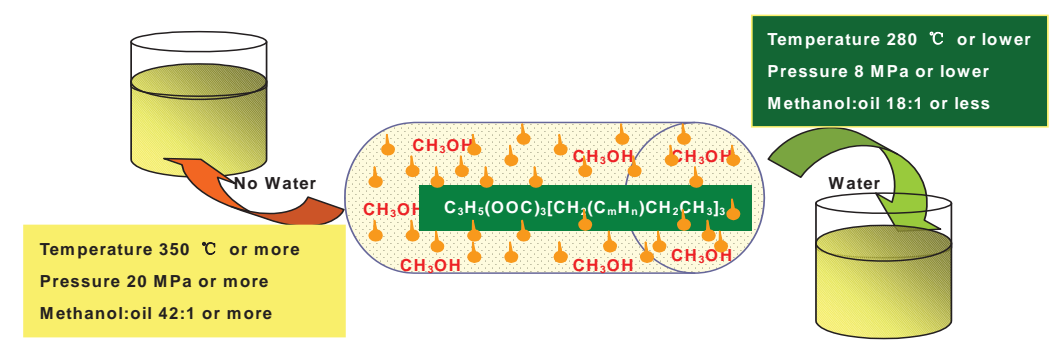

The presence of water in the sub-critical methanol method catalyzed the alcoholysis reaction of triglycerides, which reduces significantly the severity of the reaction conditions, such as temperature, pressure, and methanol to oil molar ratio.

\section{0}

[32] Tang Zh, Du Z X, Min E Z, Gao L, Jiang T, Han B X. Fluid Phase Equilibria, 2006, 239: 8

[33] Shimoyama Y, Iwai Y, Jin B S, Hirayama T, Arai Y. Fluid Phase Equilibria, 2007, 257: 217

[34] Fang T, Shimoyama Y, Abeta T, Iwai Y, Sasaki M, Goto M. J Supercrit Fluids, 2008, 47: 140

[35] Shimoyama Y, Abeta T, Iwai Y.J Supercrit Fluids, 2008, 46: 4

[36] Shimoyama Y, Abeta T, Zhao L, Iwai Y. Fluid Phase Equilibria, 2009, 284: 64

[37] Hegel P, Mabe G, Pereda S, Brignole E A. Ind Eng Chem Res, 2007, 46: 6360

[38] Hegel P, Andreatta A, Pereda S, Bottini S, Brignole E A. Fluid Phase Equilibria, 2008, 266: 31

[39] Glisic S, Montoya O, Orlovic A, Skala D. J Serbian Chem Soc, 2007, 72: 13

[40] Han H W, Cao W L, Zhang J Ch. Process Biochem, 2005, 40: 3148

[41] Yin J Zh, Xiao M, Song J B. Energy Conversion Management, 2008, 49: 908
[42] Sawangkeaw R, Bunyakiata K, Ngamprasertsith S. J Supercrit Fluids, 2010, 55: 1

[43] Kusdiana D, Saka S. Fuel, 2001, 80: 693

[44] Anitescu G, Deshpande A, Tavlarides L L. Energy Fuels, 2008, 22: 1391

[45] de Boer K, Bahri P A. Biomass Bioenergy, 2011, 35: 983

[46] Savage P E, Gopalan S, Mizan T I, Martino C J, Brock E E. AIChE J, 1995, 41: 1723

[47] Tang Zh. [PhD Disserttation]. Beijing: Research Institute of Petroleum Processing, SINOPEC (唐忠. [博士学位论文]. 北京: 中国石化 石油化工科学研究院), 2005

[48] Noureddini H, Zhu D. J Am Oil Chem Soc, 1997, 74: 1457

[49] Madras G, Kolluru C, Kumar R. Fuel, 2004, 83: 2029

[50] Rathore V, Madras G. Fuel, 2007, 86: 2650

[51] He H Y, Sun Sh Y, Wang T, Zhu Sh L. J Am Oil Chem Soc, 2007, 84: 399

[52] Kusdiana D, Saka S. J Chem Eng Jpn, 2001, 34(3): 383

[53] Kusdiana D, Saka S. Bioresour Technol, 2004, 91: 289

\section{废弃油脂原料 SRCA 生物柴油技术的研发与工业应用示范}

\author{
杜泽学"，唐 忠，王海京，曾建立，陈艳凤，闵恩泽 \\ 中国石油化工股份有限公司石油化工科学研究院, 北京 100083
}

\begin{abstract}
摘要: 针对废弃油脂品质差, 酸值高, 难于采用传统的碱催化酯交换技术加工生产生物柴油, 中国石化石油化工科学研究院开展 了超/近临界甲醇介质中油脂溶解和反应的基础研究, 相继解决了甲醇与油脂的互溶、降低反应条件, 三脂肪酸甘油酯和游离脂肪 酸的深度转化, 以及产品质量等问题, 成功开发了近临界醇解生物柴油技术 (以下简称 SRCA), 于 2009 年建成了 6 万吨/年工业化 示范装置, 以酸化油和餐厨废油为原料, 生产连续稳定, 产品收率高且满足国家生物柴油质量标准 (GB/T 20828-2007).

关键词: 生物柴油; 废弃油脂; 甲醇; 近临界甲醇醇解工艺 (SRCA); 酯交换; 酯化
\end{abstract}

收稿日期: 2012-08-30. 接受日期: 2012-11-08. 出版日期: 2013-01-20.

*通讯联系人. 电话: (010)82368237; 传真: (010)62311290; 电子信箱: duzexue.ripp@ sinopec.com 基金来源：国家重点基础研究发展计划 (973 计划, 2012CB224803).

本文的英文电子版由Elsevier出版社在ScienceDirect上出版(http://www.sciencedirect.com/science/journal/18722067). 


\section{1. 前言}

生物柴油是以油脂为原料生产的、性能与石油柴油 相近的液体酯类有机燃料, 不含硫和芳烃, 十六烷值高, 润滑性能好, 所以是一种优质的清洁柴油. 生物柴油是 21 世纪正在崛起的新兴产业, 全世界生产能力已超过 3000 万吨/年, 2011 年实际产量也突破了 2000 万吨 ${ }^{[1]}$. 中国政府也十分重视生物柴油的发展, 在 “十一・五” 制定的《可再生能源中长期发展规划》中确定, 2010 年 前完成生物柴油产业工业化示范, 到 2020 年将产量发 展到 200 万吨/年.

生物柴油产业发展的关键在油脂原料. 国外研究表 ${ }^{\text {明 }}{ }^{[2 \sim 4]}$, 油脂成本占生物柴油总生产成本的 $75 \%$ 以上, 而 能耗、人员成本和折旧加在一起也不超过 $15 \%$. 欧美国 家和地区一开始几乎全部使用可食用油脂, 包括大豆 油、双低菜籽油、棕榈油等生产生物柴油. 近年来, 为了 降低生物柴油的成本, 各国在使用可食用油脂的同时, 都很重视非食用油脂资源的利用. 例如美国就出台了一 些新政策, 推动减少使用大豆油生产生物柴油, 对以餐 饮废油为原料生产生物柴油给予更多的税收减免, 达到 306 美元/吨, 而从大豆油生产只减免 153 美元/吨 ${ }^{[5]}$.

我国人口多, 食用油需求量大, 国内生产的植物油 还不到需求量的 $40 \%$, 每年需要进口大量的转基因大豆 油、食用棕榈油等填补国内需求的缺口 ${ }^{[6]}$. 因此, 我国不 可能采用可食用性油脂大规模生产生物柴油. 国家制订 了以林木油为原料的 “林油一体化” 生物柴油产业发展 模式, 大力培植生物柴油能源林基地. 同时, 我国也出台 了一系列的优惠政策, 鼓励多使用废弃油脂为原料生产 生物柴油.

利用废弃油脂制备生物柴油的研究很活跃 ${ }^{[7 \sim 12]}$, 目 的是要解决液体酸碱工艺存在的缺陷. 液体酸碱法工艺 先对废弃油脂进行催化酯化脱酸处理, 再采用碱催化酯 交换反应, 最后对粗产品进行精制得到高品质的生物柴 油. 由于常用的酸碱催化剂是硫酸- $\mathrm{NaOH}$ 或 $\mathrm{KOH}$, 因 此存在一些难以解决的问题, 如副反应多而降低了原料 的利用率, 严重的腐蚀导致故障率高, 无计划停产事故 多, 废渣和污水排放多、处理难度大, 费用高等. 因此固 体强酸或碱的催化技术 ${ }^{[13]}$, 酶催化技术 ${ }^{[14]}$ 和超临界技 术等 ${ }^{[15]}$ 成为研究的热点. 其中中国石化石油化工科学 研究院在闵恩泽先生的倡议和指导下, 开发了近临界甲 醇醇解 (SRCA) 技术. 该技术具有原料适应性广, 利用 率高, 生产过程清洁和产品质量稳定的特点, 建成的 6
万吨/年生物柴油工业装置已经稳定运行生产, 这是 SRCA 工艺首次大规模工业化的成功应用 ${ }^{[16]}$.

\section{2. 废弃油脂的资源和品质特征}

\section{1. 废弃油脂的资源分析}

废弃油脂是食用油和肉类食品在生产加工和食用 消费过程中产生的, 包括餐饮废油、存放过期的食用油、 酸化油和非食用的动物脂肪等, 它们来源于生物, 具有 可再生性. 废弃油脂每年的产出量很大, 以植物油为例, 2009/2010 年度全球大豆等 9 大类植物油的总产量为 13877 万吨 ${ }^{[17]}$; 这些植物油经加工和消费后, 将产生占 其总量约 20\% 30\% 的废弃油脂 ${ }^{[18]}$, 即 3000 万吨以上. 如果再考虑废动物脂肪, 则数量更大.

就中国来说, 由于传统饮食习惯, 煎炒烹调炸加工 食品, 不仅要使用比较多的油, 也决定了油脂的有效利 用率低于西方国家, 每年产出的废弃油脂将更多. 但废 弃油脂的产量没有明确的数量. 笔者通过多方收集数 据, 进行了细致的分析发现, 我国每年废弃油脂的产出 量不低于 1000 万吨, 依据如下.

餐饮废油: 俗称地沟油, 主要指城市宾馆、饭店、餐 馆和居民日常生活使用油脂时产生的不宜食用的废弃 油脂,包括餐余油、煎炸余油、潲水油等. 餐饮废油的产 出量没有权威的统计数据, 可根据食用油的食用率来估 计. 西方国家公布的食用率约 75\%, 我国因传统的饮食 习惯, 食用率不可能高于西方国家, 按与西方国家相同 的食用率保守估计, 就有 $25 \%$ 的食用油脂变成餐饮废 油. 如 2011 年我国食用油消费量达 2765 万吨 ${ }^{[6]}$, 其中 约 2000 万吨是在城市食品工业中消费的, 估计产出的 餐饮废油为 500 万吨.

存放过期的食用油: 食用油在储存、销售和消费过 程中, 不可避免会有一部分超过保质期, 不宜食用; 另 外，储罐的清底、清洁等过程也要产生不宜食用的油脂. 根据预测每年约有 100 万吨食用油因存放过期而需要 处理.

动物油脂: 中国猪、牛、羊、鸡、鸭等存栏量都居 世界前列, 产肉的同时也副产大量的脂肪. 根据统计局 公布的肉产量估计, 2011 年我国肉类总产量达 7957 万 吨, 按 $15 \%$ 计约副产各类动物油脂 1200 万 吨 ${ }^{[19]}$, 其中 优质脂肪除作为食用外, 主要作为油脂化工的原料. 而 一些品质较差的脂肪, 异味大, 不适宜做油脂化工的原 料, 但可以作为生物柴油原料, 这部分脂肪的数量估计 约 400 万吨. 
酸化油: 由植物毛油精炼生产食用油产生的含油下 脚料酸化加工得到的高酸值油脂. 植物毛油精炼产生的 含油下脚料包括水化油脚、㿝脚和脱臭馏出物 (又称 DD 油). 我国每年加工的各种植物毛油 2056 万吨 ${ }^{[6]}$. 这些 含油下脚料的产出率 (相对于毛油)、产量、含油率以及 生产的酸化油如表 1 所列. 可以看出, 这些下脚料能够 生产出 106 万吨的酸化油. 酸化油通常可以用来生产混 合脂肪酸, 但近年来混合脂肪酸也多用作生产生物柴油. 因此, 用作生产生物柴油的酸化油估计.

\section{2. 废弃油脂的品质特征}

废弃油脂种类繁杂, 来源渠道多, 初加工技术粗放, 缺乏统一的质量评定方法. 为了把握废弃油脂的品质特 性, 使评定结果能够与其加工性能相呼应, 本课题组对 近 10 年来收集的近千个样品进行了大量的分析和检测. 多年的实践表明, 当前食用油脂的分析检测方法不适用 于废弃油脂. 另外, 要完全确认废弃油脂样品的组成是 很困难的, 因为其中的化合物数量多, 某些化合物分子 量大、含量低, 受热和受光都可能发生变化, 没有对应的 有效分析方法. 实际上, 可转化为生物柴油的只是可皇 化物, 不能转化为生物柴油的物质, 知道了其详细其组 成用途不大. 为此, 本着实用、直观和评定快捷的要求, 仅把可皇化物含量、酸值、水分、固体颗粒杂质 (固杂) 含量和其它胶溶性杂质 (胶杂) 作为评价废弃油脂质量 的检测指标; 其中可皇化物含量是关键指标, 并为此建 立了专门的分析方法. 表 2 列出了国内外不同种类废弃 油脂的质量品质特征. 可以看出, 不同种类废油脂品质 的差异很大. 港澳及日本的废油脂品质优于中国大陆. 这主要是由于这些地方垃圾分类比较严格, 废油脂未出 家庭或餐馆就已经得到分离. 这些废油脂由于酸值相对 低, 可通过脱酸和脱胶达到碱催化酯交换反应的要求. 因此, 日本利用餐厨废油生产生物柴油仍然采用碱催化 酯交换技术.

\section{3. 废弃油脂的用途及其能源化利用的意义}

废弃油脂量大、种类多、来源分散、收集困难, 一 旦处置失当, 将成为严重的污染源, 破坏土地, 污染水体 和大气, 危害居民健康 ${ }^{[20]}$.

废弃油脂曾用作动物饲料添加剂或洗涤剂原料, 但 后来发现这种使用将延续其对人类的危害, 只能以污染 物进行无害化处理, 但处理难度大, 费用高 ${ }^{[21]}$. 近年来, 废弃油脂的资源化利用受到各国的重视, 被看作重要的 石油替代资源之一. 日本采用废煎炸油生产生物柴油已 经发展到 40 万吨/年的规模, 既减少了废煎炸油对环境
的污染, 又生产出了市场需要的清洁生物柴油 ${ }^{[22]}$.

以废弃油脂为原料生产生物柴油是废弃油脂利用 的最好途径, 其优势表现在: (1) 采用废弃油脂生产生物 柴油具有全年不分季节供应, 不需要培养木本油料树的 早期投入; (2) 生产生物柴油对废弃油脂质量要求不象 生产油脂化学产品那么严格, 更多种类的废弃油脂可得 到应用; (3) 废弃油脂价格便宜, 往往不到油脂食用油的 $70 \%$, 原料成本相对较低; (4) 生物柴油作为柴油的替代 品在国内市场缺口大, 销售前景好.

利用废弃油脂生产生物柴油更加符合中国的国情. 中国不支持利用可食用油脂发展生物柴油, 但高度重视 废弃油脂生物柴油产业的发展. 充分利用废弃油脂生产 生物柴油, 不仅把废弃资源转变为清洁能源, 有效减少 其对环境的污染, 而且避免其经过处理重返餐桌, 保障 了食品安全. 发展废弃油脂产业将为林木油脂生物柴油 产业发展打下装备基础, 积累发展经验。“林油一体化” 是国家提倡的生物柴油产业发展模式. 但是, 油料树的 培育、生长、结果到稳定产油需要相当长的时间. 在产 业发展前期, 果实数量有限, 远远不能达到装置规模要 求的数量. 此时如果建设了装置, 由于原料不能足量供 应, 装置难以长期运转, 生产效益不能得到发挥; 如果不 建设装置, 早期收获的果实不能卖出, 将打击种植业的 积极性, 最终影响整个产业的健康发展. 率先发展废弃 油脂生物柴油产业, 利用废弃油脂原料的生物柴油厂收 购加工林业基地早期收获的果实生产生物柴油, 保护了 林业种植业者的积极性. 待林业基地稳产后, 建设新装 置生产生物柴油, 使 “林油一体化” 的生物柴油产业发 展模式得以健康发展.

\section{SRCA 工艺研发中解决的一些关键问题}

废弃油脂生产生物柴油国内早在 2002 年就已经开 始工业化, 采用的技术是改进的传统酸碱法 ${ }^{[23,24]}$. 针对 废弃油脂酸值高的特点, 先采用了酸催化剂催化酯化降 酸; 降酸达到要求后, 脱除无机酸催化剂, 再用强碱催化 剂催化酯交换反应, 使甘油脂肪酸酯进一步转化为脂肪 酸甲酯. 考虑到成本、设备材质的选择等问题, 酸催化剂 为硫酸, 碱催化剂多是 $\mathrm{NaOH}$. 该工艺对原料要求不高, 操作比较灵活, 但实际生产中遇到的问题往往难以解决. 用硫酸作催化剂进行降酸, $90 \%$ 的游离脂肪酸 (FFA) 能 在 $60 \mathrm{~min}$ 内转化, 剩下的 $10 \%$ 往往需要反应 $120 \mathrm{~min}$ 才 能达到碱催化醇解工序的要求. 然而, 延长反应时间使 得副反应增多而降低了收率, 同时腐蚀加剧引发了更多 
的设备故障. 因此, 固体酸催化技术一直是研究热点, 但 固体酸催化剂使用寿命问题还未突破, 阻碍了工业化的 应用开发 ${ }^{[25,26]}$. 用 $\mathrm{NaOH}$ 等强碱催化酯交换反应, 其效 果显著, 但其诱发的㿝化副反应使得降低了原料的利用 率, 同时㿝在换热器上结垢, 影响换热效果, 而水洗时产 生㿝化, 轻时损失产品收率, 严重时水油混合在一起, 无 法继续生产下去, 只能停产处置.

综上可见, 酸碱法技术存在资源利用率低, 腐蚀和 环保等问题. 因此, 只有开发出不用酸碱催化剂的新技 术, 问题才能得到根本的解决, 这就是超临界甲醇醇解 新技术的研发受到重视的原因. 但研究表明 ${ }^{[27,28]}$, 原料 的高转化率是建立在苛刻的反应条件上, 如反应温度 $350{ }^{\circ} \mathrm{C}$ 以上, 反应压力 $19 \mathrm{MPa}$, 甲醇与油的摩尔比 42 , 这意味着设备投资能耗增加. 因此, 只有降低反应条件 的同时还能获得高产品收率, 超临界甲醇醇解技术的应 用才有出路. SRCA 工艺就是按照这个要求, 不断解决 面临的各种关键性问题, 才成功实现了工业化示范应用.

\section{1. 甲醇与原料油脂的溶解}

众所周知, 常温常压下甲醇与油脂几乎不相溶, 很 不利于它们之间发生反应. 搅拌或加入共溶剂能促进甲 醇与油脂的混合 ${ }^{[29-31]}$. 然而, 在超临界甲醇的条件下使 用摚拌会给摚拌轴的密封带来麻烦, 而且能耗增加. 因 此, 弄清楚升温升压到甲醇临界状态过程中, 甲醇油脂 体系相平衡的变化规律很有必要. 我们这方面的研究从 2003 年开始, 研究结果 2006 发表后 ${ }^{[32]}$, 相继才有类似 文章发表. 其中, 日本的 Shmoyama 等 ${ }^{[33-36]}$ 研究了产物 甲酯-甲醇和副产物甘油-甲醇体系在超临界甲醇条件下 气-液平衡和液-液相平衡的规律, 温度范围 $220 \sim 270^{\circ} \mathrm{C}$, 最高到 $300^{\circ} \mathrm{C}$; 压力范围 2.16 8.78 MPa, 最高到 11.45 MPa. Hegel 等 ${ }^{[37,38]}$ 研究的是用丙烷作共溶剂时反应前 后混合物体系在超临界甲醇条件下的相行为, 研究温度 范围 270 315 ${ }^{\circ} \mathrm{C}$; 压力范围 7 21.1 MPa. Glisic 等 ${ }^{[39]}$ 研 究葵瓜籽油-甲醇体系的气-液平衡行为及对合成转化的 影响, 研究温度范围 20 230 ${ }^{\circ} \mathrm{C}$; 压力范围 2.9 5.6 MPa. 相较之下, 我们当初选择的研究对象是菜籽油 (Canola 油), 目的是研究升温升压过程中甲醇与菜籽油未明显开 始反应前二者相平衡的变化规律. 考虑到甲醇与油脂在 高温高压 $\left(>240{ }^{\circ} \mathrm{C},>8.0 \mathrm{MPa}\right)$ 下将开始发生较明显的 反应, 使得体系的组成随时间不断发生变化, 增加了相 平衡研究的复杂性. 因此, 拟定的研究条件是温度 80 200 ${ }^{\circ} \mathrm{C}$, 压力 4.0 10.0 MPa. 实验证实, 在没有催化剂 作用时, 在该条件下体系在达到相平衡的时间范围内,
化学反应可以忽略. 将得到的甲醇与油脂体系的相平衡 数据, 采用 Dohrn 和 Brunner 提出的方法根据组分的液 相摩尔体积和蒸汽压数据推算甘油三酸酯及相应脂肪 酸的临界性质. 通过状态方程的拟合来关联预测甲醇油脂体系在较宽范围内的相平衡数据. 选用 Peng-Robinson (PR) 方程, Redilich-Kwong-Aspen (RKA) 方程等适用于高压体系的状态方程在 Aspen Plus®10.1 模拟系统中分别对甲醇-油脂体系高压流体的相平衡进 行关联, 获得了二元相互作用参数和极性因子等状态方 程参数. 将计算值与实验值进行了比较, 得出平均偏差 分别为 $1.73 \%$ 和 $0.30 \%$, 最大偏差为 $13.63 \%$ 和 $4.44 \%$. 研究还发现, 升高温度有利于甲醇在油脂中的溶解; 但 压力变化后甲醇在油脂中的溶解行为比较复杂, 具体示 于图 1. 可以看出, 温度不超过 $150{ }^{\circ} \mathrm{C}$ 时, 相同温度下, 压力升高, 甲醇在菜籽油中的溶解度下降; 温度超过 $150{ }^{\circ} \mathrm{C}$ 、压力超过 $8.0 \mathrm{MPa}$ 时, 温度和压力升高都有利于 增加甲醇在菜籽油中的溶解度. 根据图 1 可以预测, 体 系处于甲醇临界点以上时, 甲醇在菜籽油中的溶解度不 再受温度和压力变化的影响. 在此研究的基础上, 通过 状态方程的拟合来预测较大范围的相平衡数据, 并将发 生化学反应后体系组成变化 (依据动力学数据) 与相平 衡之间的相互影响结合起来, 从而进一步了解了甲醇与 油脂体系超临界醇解反应的过程与结果, 对后来优化反 应压力具有指导作用.

在超临界甲醇反应体系中引入共溶剂的目的是促 使甲醇与油脂相互溶解, 以促进反应, 提高生物柴油收 率. 2004 年我们研究共溶剂时, 相关报道还很少. 我们 所选的溶剂包括正己烷、环己烷、正庚烷等烃类化合物, 生物柴油、乙酸乙酯、乙酸丁酯等酯类化合物. 为了回 避废弃油脂中杂质可能产生的干扰, 以质量相对好的氢 化油煎炸余油作为原料进行实验, 反应条件是温度 300 ${ }^{\circ} \mathrm{C}$ 、压力 $12 \mathrm{MPa}$, 醇油质量比 (以下简称醇油比) 0.66 , 反 应时间 $30 \mathrm{~min}$. 试验结果表明, 一方面加入共溶剂能明 显地促进了反应, 使收率增加了近 20\%; 另一方面不同 共溶剂表现了不同的效果, 其中酯类化合物在添加量相 对少时, 效果优于烷烃类溶剂, 但溶剂用量增加后, 短碳 链的酯类溶剂效果有所变差.

在溶剂分离试验中发现, 烷烃类溶剂的体积和组成 基本没有变化, 而短碳链酯类溶剂不仅体积减小, 而且 组成也发生变化, 变成了原溶剂和乙酸甲酯的混合物. 这说明烷烃类共溶剂稳定, 酯类共溶剂参与了反应. 因 此, 短碳链类酯类溶剂不适宜作为共溶剂. 
由此可见, 共溶剂的加入只在一定程度上改善了反 应, 但收率不到 $80 \%$, 而且反应后需要分离溶剂, 势必增 加能耗.

可见, 加入共溶剂并不是解决甲醇油脂相互溶解问 题的好方案. 我们从后来开展反应时间的条件试验得到 了启发, 通过深入研究获得了较好的解决方案, 不需要 外加任何共溶剂. 反应时间对油脂转化的影响及试验现 象见表 3. 其中, 反应时间是用反应器的有效体积除以 每分钟进的油的体积换算得到的. 可以看出, 不同反应 时间取出的样品, 进行沉降分层时现象不同, 相对短反 应时间和长反应时间的样品分两层, 但上下层的组成截 然不同. 反应 $5 \mathrm{~min}$ 的样品, 上层以甲醇为主的甲醇层, 下层是油层; 反应 $30 \mathrm{~min}$ 的样品, 上层是油层, 下层是 以甘油为主的甘油层. 而反应 10 和 $15 \mathrm{~min}$ 的样品没有 分层, 呈现均一相, 这是曾经研究共溶剂时希望达到的 理想效果.

基于表 3 结果, 我们分别用其中停留 10 和 $15 \mathrm{~min}$ 试验累积的油样 (ST10 和 ST15) 进一步进行反应试验, 结果如图 2 所示. 可以看出, 两种样品中油脂的转化在 前 $20 \mathrm{~min}$ 还有一些差别, $20 \mathrm{~min}$ 后基本一致; $30 \mathrm{~min}$ 后, 随着反应时间延长, 收率只略有增加, 说明反应达到 平衡状态. 而且同样反应 $30 \mathrm{~min}$, 这种均相物料的反应 转化效果明显好于加入共溶剂促进的效果, 收率增至 $85 \%$ 左右.

ST10 和 ST15 样品化学组成的分析结果列于表 4 . 由表可见, ST10 和 ST15 样品是原料 (三脂肪酸甘油酯 (TG)、FFA、中间产物 (二脂肪酸甘油酯 (DG) 和单脂肪 酸甘油酯 $(\mathrm{MG})$ )、产物 (脂肪酸甲酯 (FAME) ) 和甲醇的 混合物. 从分子结构分析, DG、MG 和 FAME 都有促溶 作用, 特别是 $\mathrm{DG}$ 和 $\mathrm{MG}$ 既有非极性的长脂肪酸链, 又 有强极性的甘油基团, 是共溶剂要求的理想结构, 因而 对反应有更好的促进作用, 尤其它们是中间产物, 无需 添加, 与甲醇反应就生成了产品, 不存在分离问题.

通过进一步研究, 确定了物料通过发生部分反应形 成互溶均相体系的解决方案, 设计制造了集物料加热与 预反应为一体的复合设备, 应用结果表明, 能够达到设 定的要求.

有关共溶剂的报道从 2005 年后开始增多, 研究的 共溶剂包括丙烷 ${ }^{[30,39]}, \mathrm{CO}_{2}{ }^{[40]}$, 正已烷 ${ }^{[29,41]}$ 等. 从报道的 结果看, 使用 $\mathrm{CO}_{2}$ 和丙烷目的是降低操作条件, 但降低 醇油比和温度, 转化率也下降; 压力可在保证转化率的 情况下有所降低. 使用正己烷等溶剂, 可以使温度和压
力有所降低, 可分别降低到 $280^{\circ} \mathrm{C}$ 和 $10 \mathrm{MPa}$, 但醇油比 要适当增加, 否则转化率下降.

\section{2. 降低反应条件与反应深度转化矛盾的解决}

对于超临界甲醇醇解生物柴油技术来说, 至关重要 的反应条件包括温度、压力、醇油比和反应时间. 一直 以来, 总认为高温、高压、高醇油比和短反应时间是超 临界甲醇醇解技术特征, 是获得原料高转化率的基本要 求 $^{[42 \sim 45]}$. 但高温、高压和高醇油比均会增加成本, 所以要 尽量降低反应温度、压力和醇油比, 同时又要保持高的 产品收率, 这才是 SRCA 工艺开发中必须突破的技术关 键.

从理论上说, TG 和 FFA 能够发生反应是因为甲醇 处于超临界状态时, 发生化学反应可能因偏摩尔体积的 变化而改变平衡常数, 并且传质扩散等因素改善而使反 应速率提高 ${ }^{[46]}$. 我们利用 NIST 数据库及其它文献提供 的数据, 计算出了超临界甲醇醇解反应的平衡常数 $K^{0}{ }_{298}$ $=4.485 \times 10^{9}, K_{573}^{0}=24.292$. 可见, 升高温度不利于平衡 转化率的提高, 说明超临界甲醇条件下的醇解反应是放 热反应 ${ }^{[47]}$.

动力学研究表明 ${ }^{[47]}$, 在临界甲醇温度和压力以上的 条件下, 甲醇和油脂在连续流动的管式反应器中分 3 步 进行无催化醇解反应, 中间产物包括甘油二酸酯与甘油 单酸酯; 在解决甲醇与油脂互溶问题后, 油脂与甲醇在 250 350 ${ }^{\circ} \mathrm{C}$ 范围内反应的动力学控速步骤是醇解反应. 通过对反应速率方程 (微分方程组) 的迭代求解, 得出的 连串反应各步正逆反应的速率常数与温度的关系图 (见 图 3), $\ln k$ 对 $1 / T$ 的变化关系不是完全线性的, 说明在超 临界甲醇条件下的醇解反应机理与研究拟定的机理存 在差异, 根据试验数据计算得到的各步醇解反应速率常 数只反应了某一段时间内的宏观反应速率. 根据 $\ln k \sim 1 / T$ 关系图拟合出的各步正逆反应的活化能在 $15 \sim 80 \mathrm{~kJ} / \mathrm{mol}$ 的范围 (见表 5), 比文献报道的常压碱催化 条件的测定结果有所不同 ${ }^{[48]}$. 但无催化剂的超临界甲 醇醇解和碱催化醇解的第二步, 即 DG 转变为 $M G$ 的反 应活化能接近, 说明 DG 发生醇解反应无论有无催化剂 时都需要克服更高的能垒; 第二步和第三步反应的活化 能与碱催化的有一定的差距. 由此说明, 甲醇与 DG 的 醇解反应对整个反应速率的影响较大. 文献中有关超临 界甲醇介质中 $\mathrm{TG}$ 醇解反应动力学的研究结果 ${ }^{[43,49 \sim 51]}$, 一般是在间歇反应器中得到的, 而且对反应机理和动力 学速率方程进行了简化, 所得结果对了解反应进程具有 一定的参考价值, 但与实际反应历程偏差较大. 作为连 
续管式反应器中的动力学研究, 我们的研究是首次报道.

以上化学热力学和动力学研究表明, 升高温度不利 于原料的深度转化, 能满足反应速率的要求即可; 加快 反应转化的关键是创造条件促使 TG 与甲醇反应生成 中间产物. 对于废弃油脂来说, 还要考虑 FFA 的转化及 其对 TG 转化的影响.

对于废弃油脂, 包括大豆酸化油、棕榈酸化油、煎 炸余油、餐厨废油和棕榈油酸等考察了温度、压力和醇 油比对其转化的影响. 结果见图 4. 由图可见, 对于酸值 较低的煎炸余油, 其脂肪酸甲酯的收率随温度升高而增 加, 从 $220{ }^{\circ} \mathrm{C}$ 的 $70 \%$ 左右增加到 $350{ }^{\circ} \mathrm{C}$ 的 $90 \%$ 以上; 而对于酸值较高的原料油, 收率随温度先升高后下降, 而且峰值的分布区域在 $260 \sim 300{ }^{\circ} \mathrm{C}$ 中间, 超过 $300{ }^{\circ} \mathrm{C}$ 开始下降, 且酸值越高, 收率下降相对也越多. 另外, 在 甲醇的临界压力以上, 升高压力对收率没有明显的影响. 随着醇油比的增加, 收率增加, 至醇油比为 0.88 (相当于 醇油摩尔比 24:1) 时再增加甲醇用量, 收率增加得少.

将上述研究结果与原料油酸值进行关联可以发现, 升高温度和压力只对酸值低的棕榈煎炸余油、氢化油煎 炸余油有利. 对于其它酸值较高的油, 温度和压力有最 优值, 尤其是酸值更高的棕榈油酸表现得更为突出. 这 说明在相同的反应条件下, 物料的酸值对其转化产生决 定性的影响, 控制好原料的酸值就有可能在相对缓和的 反应条件下达到油脂深度转化的目的.

进一步的试验结果证明 ${ }^{[16]}$, 在相对温和条件下, 即 260 $280{ }^{\circ} \mathrm{C}, 6 \sim 8 \mathrm{MPa}$, 醇油比 $0.44 \sim 0.88$, 对于原料油酸 值超过 $50 \mathrm{mg} \mathrm{KOH} / \mathrm{g}$ 一般能保证好的转化效果. 那些 酸值低的原料油如果加入高酸值的油或脂肪酸酸值提 高到 $50 \mathrm{mg} \mathrm{KOH} / \mathrm{g}$ 以上, 在同样温和的条件下也可取得 好的转化效果, 生物柴油的收率一般将达到 $95 \%$ 左右.

上述结果说明原料油脂肪酸的存在不仅能够缓和 反应条件, 而且促进了 $\mathrm{TG}$ 的进一步转化, 意味着脂肪 酸似乎起到了催化剂的作用, 与文献[52]结果类似. 但 我们认为脂肪酸很难起到催化剂的作用. 众所周知, TG 的酯交换是酸和碱均可催化的平衡反应. 但酸和碱催化 的机理完全不同: 碱催化机理是碱直接与甲醇作用形成 甲氧基离子, 然后进攻 $\mathrm{TG}$ 分子发生反应, 大大缩短反 应达到平衡的时间, 效率高. 而酸催化剂是其电离出来 的 $\mathrm{H}^{+}$与 $\mathrm{TG}$ 分子中酰基上的氧结合, 形成活性中间体, 再与醇分子起反应, 该催化过程一方面受到酸催化剂在 甲醇中的电离程度的影响, 另一方面, $\mathrm{H}^{+}$与 $\mathrm{TG}$ 形成的 活性中间体, 空间位阻大, 甲醇分子接近难度大, 因此,
酸催化的酯交换反应达到平衡转化率的时间长. 脂肪酸 分子相对较大, 在甲醇中电离程度很低, 生成的 $\mathrm{H}^{+}$浓度 也很低, 难以起到催化作用.

实际上, FFA 发生酯化反应生成了水, 后者真正起 催化作用. 在超临界甲醇介质中, 甲醇自身解离作用增 强, 形成较多的甲氧基离子, 同时还会与体系中的质子 形成相应的质子化物, 从而促进 TG 和 FFA 反应, 而且 大大缩短反应达到平衡的时间. 可见, 超临界甲醇介质 中的反应机理与酸碱催化的完全不同.

但超临界甲醇的解离与缔合相互矛盾的, 缔合态的 甲醇必须解除缔合成为单分子才可能发生解离. 在高压 下, 甲醇的局部密度增强效应会促进甲醇缔合, 醇油摩 尔比高也会促进甲醇的缔合, 但升高温度有利于解除缔 合, 促进甲醇解离. 但是, 水的存在会影响甲醇的缔合平 衡, 水的极性大, 与甲醇更容易结合在一起, 从而破坏了 甲醇缔合体, 客观上起到了增加甲醇解离的作用, 提供 了更多的活性态基团. 当原料油中 TG 和 FFA 共存时, 甲醇解离生成活性态基团, 由于 FFA 分子相对小, 空间 位阻小, 更易发生反应, 生成脂肪酸甲酯的同时, 还生成 了水. 生成的水与甲醇结合, 破坏了甲醇的缔合平衡, 同 时与甲醇解离出来的 $\mathrm{H}^{+}$结合, 进攻 TG, 使 $\mathrm{TG}$ 发生水 解反应生成脂肪酸, 从而间接降低了 $\mathrm{TG}$ 反应生成脂肪 酸甲酯的条件要求. Kusdiana 等 ${ }^{[53]}$ 也认为, 超临界甲醇 中的水起到了类似酸催化剂的作用, 其酸性比甲醇强, 能够促进 TG 的醇解反应, 但不会增加甲酯的收率.

\subsection{SRCA 技术的工业示范应用}

采用 SRCA 工艺设计建设的第一套工业化示范装 置于 2009 年建成投产, 装置的规模是 6 万吨/年生物柴 油, 采用的原料包括大豆酸化油、棕榈酸化油、餐饮废 油等, 原料性质及运行结果如表 6 所列.

示范装置生产的生物柴油产品经检测, 其各项指标 都能满足国标 GB/T 20828 的要求.

\section{4. 结论}

废弃油脂资源丰富, 用来生产绿色清洁的生物柴油 是避免其危害环境的最好办法. 超临界甲醇醇解法对原 料酸值要求低, 适应加工废弃油脂, 但过高的温度、压力 和醇油比必然增加生产成本. 甲醇-油脂体系相平衡热 力学行为规律的研究表明, 体系处于甲醇临界条件以下 时, 升高温度有利于甲醇在油脂中的溶解, 但升高压力 会减少甲醇在油脂中的溶解度; 体系处于甲醇临界条件 以上时, 甲醇在油脂中的溶解度不再受温度和压力的影 
响. 研究发现, 通过加入反应中间产物 MG 和 DG 能够 解决体系进入甲醇临界条件前甲醇与油脂的溶解问题, 为体系进入超临界甲醇条件后的快速反应打下基础. 临 界甲醇条件下油脂醇解反应动力学研究表明, 甲醇和油 脂的醇解反应分 3 步进行, 中间产物包括 $\mathrm{DG}$ 与 $\mathrm{MG}$, 反 应转化的关键步骤是 DG 与甲醇的醇解生成 MG 的反 应. 研究发现, 升高温度、压力和增加醇油比并不总是利 于反应的深度转化; 酸值对废弃油脂的深度转化至关重
要, 其内在的原因是游离脂肪酸与甲醇反应生成的水对 $\mathrm{TG}$ 醇解反应具有催化作用, 降低了对反应条件的要求. 据此开发的 SRCA 生物柴油工艺已经顺利实现工业化 应用, 产品酸值可满足现有国标 (GB/T 20828) 规定的不 大于 $0.8 \mathrm{mg} \mathrm{KOH} / \mathrm{g}$ 油的要求. 然而, 欧美标准和我国即 将发布的新修订国标对产品酸值有更高的要求, 即不大 于 $0.5 \mathrm{mg} \mathrm{KOH} / \mathrm{g}$ 油. 这将对超临界甲醇醇解工艺提出 更高的要求, 也是未来技术攻关的方 向. 